\title{
Seroprevalence of Toxoplasma gondii among a group of Egyptian patients with type I diabetes mellitus
}

\author{
Hala M. Khattab', Safeya O. El Bassiouni ${ }^{2}$, Manal H. Abuelela ${ }^{3 *}$ (D) and Dalia O. Abd Elsalam
}

\begin{abstract}
Background: Toxoplasmosis is probably one of the most common parasitic infections of humans. While infection of healthy adults is usually relatively mild, serious disease can result in utero or when the host is immunocompromised. Toxoplasmosis in diabetic patients may occur due to recently acquired acute infection or they may suffer from dissemination of reactivated latent infection. In the present study, the antinuclear antibody prevalence was tested to determine the possible relationship with Toxoplasma seroprevalence and clinical findings in type I diabetic patients.
\end{abstract}

Methods: Toxoplasma gondii antibodies were tested serologically in 60 patients of type I diabetes mellitus and 60 controls using ELISA technique.

Results: The seropositivity for anti-Toxoplasma lgG antibodies in the study groups was $45 \%$ in type I diabetes mellitus patients (group 1) and $23.3 \%$ in the control (group 2) with $p$ value $=0.012$ showing a statistically significant difference between groups, while only three patients of diabetes type1 group were positive for anti-Toxoplasma $\operatorname{lgM}$ with $p$ value $=0.244$ showing no statistically significant differences between the two groups. Results showed that only one patient of diabetes type 1 (group1) had positive ANA and one control (group2) had positive ANA. Thus, no correlation could be detected from such results.

Conclusion: The study results showed a statistically significantly higher proportion (45\%) of seropositivity antiToxoplasma IgG antibodies among type I diabetes mellitus patients compared to $23.3 \%$ among the control group, while there was no association could be detected between the studied groups regarding the ANA.

Keywords: Toxoplasma gondii, Diabetes mellitus, ANA, ELISA, IgG and IgM antibodies

\section{Background}

Toxoplasma gondii is a ubiquitous, apicomplexan parasite of warm-blooded animals (Tenter et al. 2000). Toxoplasmosis is probably one of the most common parasitic infections of humans. While infection of healthy adults is usually relatively mild, serious disease can result in utero or when the host is immuno-compromised (Jones et al. 2001 and Dubey 2005).

Toxoplasma infection is ranked among the most commonly occurring opportunistic infections in AIDS patients and may well be a greater direct cause of

\footnotetext{
*Correspondence: Manal_elela@yahoo.com; m.abuelela@rio.edu.eg; publicmha@gmail.com

${ }^{3}$ Public Health Department, Research Institute of Ophthalmology, Giza, Egypt

Full list of author information is available at the end of the article
}

morbidity and mortality than other more common opportunistic infections (Dubey 2005).

Serological diagnosis of toxoplasmosis represents the most widely used approach for defining the stage of infection, ELISA showing higher sensitivity and specificity (Remington et al. 2004 and Sensini 2006).

Diabetes mellitus is a widespread metabolic complex disorder causing various dysfunctions in most of the body systems including cellular and humoral immunity. Diabetic patients were included in a classification of the immuno-compromised patients (Olefsky 1985). Insulindependent diabetes mellitus (IDDM) or type I diabetes is a debilitating chronic disease that impairs production 
and secretion of the key hormone insulin and alters blood sugar metabolism. Insulin is synthesized and secreted by pancreatic islet cells of Langerhans (Orci et al. 1988).

Toxoplasmosis in diabetic patients may occur due to recently acquired acute infection or they may suffer from dissemination of reactivated latent infection (Montoya et al. 2001). However, studies of toxoplasmosis in diabetic patients are scanty (Cavallazzi 1985 and Yamamoto et al. 2003).

As regards autoimmunity, initial studies suggested that certain infections might precipitate the onset of autoimmune pathology (Benoist and Mathis 2001). With the improvement of living standards, the prevalence rate of diabetes has steadily increased. The sensitivity and susceptibility to various infections can be higher in diabetes mellitus patients (Joshi et al. 1999). In some cases, Toxoplasma gondii has been proposed as a possible cause of diabetes, and current information is nearly predicated on this issue (Shin et al. 2009 and Shirbazou et al. 2013).

Circulating auto-reactive antibodies such as anti-nuclear antibodies (ANA) play a central role in the diagnosis and classification of autoimmune disorders. Auto-reactive antibodies can appear long before the onset of clinical disease, and detection of these antibodies in serum has been shown to have strong predictive value (Youinou et al. 2010).

The aim of the present work was to study the seroprevalence of Toxoplasma gondii among a group of patients with type I diabetes mellitus and to consider the possible relationship between diabetes mellitus, Toxoplasma gondii infection, and auto-reactive antibodies using ELISA technique.

\section{Materials and methods \\ Participants}

A case-control study was carried out in the diabetes clinic at the Research Institute of Ophthalmology (RIO), Giza City, Egypt, over a period of 7 months. All studied patients gave informed written consent before the involvement in the study. The study was conducted in accordance with the Declaration of Helsinki, and the protocol was approved by the Ethics and Research Committee of RIO.

\section{Sample size calculation}

Using the WHO manual for sample size determination in health studies, the sample size was determined by using the proportion difference approach with the assumption of $95 \%$ confidence level, $80 \%$ power, control to case ratio $1: 1$, the odds ratio to be detected $\geq 2$, and the $30 \%$ control group will be exposed (Chadha 2006). The minimal sample size required 52 cases and 52 controls with a total of 104. To account for possible non-response and for more precision, $15 \%$ was added to give a total sample of 120 subjects (60 cases and 60 controls).

\section{Study design}

The case group comprised 60 patients with type I diabetes mellitus (T1DM) in the age group of 15-60 years who were diagnosed with T1DM based on WHO criteria (WHO 2011) and who were receiving care at the diabetes clinic of RIO. The diabetes clinic was held twice a week and the average number of diabetic (type I) patients attending per day was two patients. The control group involved an equal number of non-diabetic subjects chosen from other outpatient clinics of RIO hospital by selecting for every case a matched age and sex control. T1DM was excluded from controls by history taking and measuring their random blood sugar. The response rates were $80 \%$ and $85 \%$ among cases and controls respectively.

All subjects in the present study were subjected to the interview questionnaire through complete history taking and clinical examination according to structural questionnaire comprised the following items:

- Name, age, gender, occupation, residence (urban/rural)

- Symptoms and signs of toxoplasmosis: medical history of fever, malaise, swelling in the neck, skin rash, diminution of vision, and history of bad outcome of pregnancy

- Risk factors for contracting toxoplasmosis: consumption of undercooked meat (ham, sausages, luncheon), consumption of unwashed vegetables and fruits, contact with cats, and contact with soil (gardening or agricultural)

- Past history of medical disease: diabetes mellitus, DM complications such as renal disease and eye manifestations, intake of immunosuppressive drugs, and history of blood transfusion

Blood samples were collected from all subjects included in the study, and the separated sera were stored at $-20{ }^{\circ} \mathrm{C}$ in duplicate vials until used. All serum samples were tested for:

1. Detection of anti-Toxoplasma antibodies (IgG and IgM) by the indirect enzyme-linked immunosorbent assay (ELISA) using the Calbiotech Toxoplasma IgG ELISA kit (catalog no: TX022G)

2. Detection of anti-nuclear antibodies (ANA) by the indirect enzyme-linked immunosorbent assay (ELISA) using the Calbiotech ANA screen ELISA kit (catalog no: AN033G)

\section{Statistical analysis}

The obtained data were entered, revised, and analyzed using the Statistical Package for the Social Sciences software (SPSS), version 18. The results were presented as frequencies and percentages. Two-tailed Fisher's exact test or 
chi-squared test $\left(\chi^{2}\right)$ were used as appropriate for comparison of categorical variables between groups. $p$ value $<0.05$ was considered as statistically significant following Bonferroni correction for multiple testing (Daniel 2005).

\section{Results}

Sociodemographic data of patients and controls are shown in Table 1, which revealed that $38(63.3 \%)$ of the patient group were living in urban areas versus 55 (91.7\%) of the control group. Patients consuming undercooked meat were significantly lower $(p=0.001)$ than those of the control group $(36.7 \%$ vs. $66.7 \%$, respectively), while $85 \%$ vs. $8.3 \%$ were in contact with cats and $90 \%$ vs. $1.7 \%$ were in contact with soil for patient and control groups respectively with highly statistically significant difference $(p<0.0001) ; 5 \%$ of cases vs. $3.3 \%$ of control were consuming unwashed vegetables.

Distribution of the patients studied and their correlation with $T$. gondii seroprevalence was shown in Table 2; anti- $T$. gondii IgG antibodies were found in 27 (45\%) of the cases and in $14(23.3 \%)$ of the control group. The seroprevalence of $T$. gondii infection was significantly higher in cases than in controls $(\mathrm{OR}=2.69 ; 95 \% \mathrm{CI}$ $1.23-5.89 ; p=0.01)$. Anti- $T$. gondii IgM antibodies were found in three (11.1\%) of 27 anti-T. gondii IgG seropositive cases group; none of the 14 anti-T. gondii IgG seropositive control had anti-T. gondii IgM antibodies. There was no statistically significant difference in the frequency of IgM seropositivity among cases and controls $(p=0.244)$. Results also showed that only one patient of group I and control group had positive ANA; thus, no possible association could be detected between the studied groups.

Table 3 revealed statistical significant differences regarding the consumption of undercooked meat, contact with cats and contact with soil, and Toxoplasma seroprevalence. There was no variation, neither with sex nor with age groups.

Table 4 showed the clinical findings in the study group I in relation to seropositivity where $12(44.4 \%)$ patients with diabetic retinopathy had positive anti-T. IgG. Also, it was found that $2(7.4 \%)$ patients with nephropathy had positive anti-T. IgG, 4 (14.9\%) patients with neuropathy, and 1 (3.7\%) patient with liver disease were

Table 1 Socio-demographic data of patients and controls

\begin{tabular}{|c|c|c|c|c|c|c|c|c|c|}
\hline & \multicolumn{2}{|c|}{ Cases } & \multicolumn{2}{|c|}{ Controls } & \multirow[t]{2}{*}{$x^{2}$} & \multirow[t]{2}{*}{$p$ value } & \multirow[t]{2}{*}{ OR } & \multicolumn{2}{|l|}{$\mathrm{Cl}$} \\
\hline & No. & $\%$ & No. & $\%$ & & & & Lower & Upper \\
\hline \multicolumn{10}{|l|}{ Gender } \\
\hline Male & 19 & 31.7 & 25 & 41.7 & 1.29 & 0.26 & 0.65 & 0.31 & 1.37 \\
\hline Female & 41 & 68.3 & 35 & 58.3 & & & & & \\
\hline \multicolumn{10}{|l|}{ Age groups } \\
\hline$<30$ years & 14 & 23.3 & 16 & 26.7 & 0.18 & 0.67 & 0.83 & 0.37 & 1.92 \\
\hline $31-60$ & 46 & 76.7 & 44 & 73.3 & & & & & \\
\hline \multicolumn{10}{|l|}{ Residence } \\
\hline Urban & 38 & 63.3 & 55 & 91.7 & 13.8 & $<0.001^{*}$ & 6.37 & 2.22 & 18.3 \\
\hline Rural & 22 & 36.7 & 5 & 8.3 & & & & & \\
\hline \multicolumn{10}{|c|}{ Undercooked meat } \\
\hline Yes & 22 & 36.7 & 40 & 66.7 & 10.8 & $0.001^{*}$ & 0.29 & 0.14 & 0.61 \\
\hline No & 38 & 63.3 & 20 & 33.3 & & & & & \\
\hline \multicolumn{10}{|c|}{ Unwashed vegetables } \\
\hline Yes & 3 & 5.0 & 2 & 3.3 & 0.21 & 0.648 & 1.53 & 0.25 & 9.48 \\
\hline No & 57 & 95.0 & 58 & 96.7 & & & & & \\
\hline \multicolumn{10}{|c|}{ Contact with cats } \\
\hline Yes & 51 & 85.0 & 5 & 8.3 & 70.9 & $<0.0001^{* *}$ & 62.3 & 19.6 & 198.4 \\
\hline No & 9 & 15.0 & 55 & 91.7 & & & & & \\
\hline \multicolumn{10}{|c|}{ Contact with soil } \\
\hline Yes & 54 & 90.0 & 1 & 1.7 & 94.3 & $<0.0001^{* *}$ & 531 & 61.9 & 4554 \\
\hline No & 6 & 10.0 & 59 & 98.3 & & & & & \\
\hline
\end{tabular}

$x^{2}$ chi square, $p$ value probability value, $C l$ confidence index, $O R$ odds ratio

${ }^{*} p=0.001$ (statistical significant difference)

${ }^{* *} p<0.0001$ high statistical significant difference

$p>0.05$ non-significant difference 
Table 2 Distribution of patients and control groups according to anti-Toxoplasma IgG, IgM, and ANA prevalence

\begin{tabular}{|c|c|c|c|c|c|}
\hline \multicolumn{2}{|l|}{ Groups } & \multirow{3}{*}{$x^{2}$} & \multirow{3}{*}{$\begin{array}{l}p \\
\text { value }\end{array}$} & \multirow{3}{*}{ OR } & \multirow[b]{2}{*}{$\mathrm{Cl}$} \\
\hline Cases & Control & & & & \\
\hline No. \% & No. \% & & & & Lower Upper \\
\hline
\end{tabular}

\section{Anti-Toxo lgG}

\begin{tabular}{llllllllll} 
Positive & 27 & 45.0 & 14 & 23.3 & 6.26 & $0.01^{*}$ & 2.69 & 1.23 & 5.89 \\
Negative & 33 & 55.0 & 46 & 76.7 & & & & & \\
Anti-Toxo IgM & & & & & & & & \\
Positive & 3 & 5.0 & 0 & 0.0 & 3.077 & 0.24 & & & \\
Negative & 57 & 95.0 & 60 & 100.0 & & & & & \\
ANA & & & & & & & & & \\
Positive & 1 & 1.7 & 1 & 1.7 & 0.0 & 0.75 & 1 & 0.06 & 16.37 \\
Negative & 59 & 98.3 & 59 & 98.3 & & & & & \\
\hline
\end{tabular}

$x^{2}$ chi square, $p$ value probability value, $C l$ confidence index, $O R$ odds ratio ${ }^{*} p=0.01$ statistical significant difference $p>0.05$ non-significant difference

Table 3 Relation between anti-Toxoplasma lgG prevalence and sociodemographic data among patients and control groups

\begin{tabular}{|c|c|c|c|c|c|c|}
\hline \multicolumn{7}{|c|}{ Anti-Toxoplasma lgG (seropositivity) } \\
\hline & \multicolumn{2}{|c|}{ Cases $(n=27)$} & \multicolumn{2}{|c|}{ Controls $(n=14)$} & \multirow[t]{2}{*}{$x^{2}$} & \multirow[t]{2}{*}{$p$ value } \\
\hline & No. & $\%$ & No. & $\%$ & & \\
\hline \multicolumn{7}{|l|}{ Gender } \\
\hline Male & 8 & 29.6 & 8 & 57.1 & 2.93 & 0.09 \\
\hline Female & 19 & 70.4 & 6 & 42.9 & & \\
\hline \multicolumn{7}{|l|}{ Age groups } \\
\hline 30 years or less & 5 & 18.5 & 2 & 14.3 & 0.12 & 0.99 \\
\hline $31-60$ & 22 & 81.5 & 12 & 85.7 & & \\
\hline \multicolumn{7}{|l|}{ Residence } \\
\hline Urban & 17 & 63.0 & 10 & 71.4 & 0.29 & 0.86 \\
\hline Rural & 10 & 37.0 & 4 & 28.6 & & \\
\hline \multicolumn{7}{|l|}{ Undercooked meat } \\
\hline Yes & 8 & 29.6 & 14 & 100.0 & 18.36 & $<0.0001$ \\
\hline No & 19 & 70.4 & 0 & 0.0 & & \\
\hline \multicolumn{7}{|c|}{ Unwashed vegetables } \\
\hline Yes & 0 & 0.0 & 1 & 7.1 & 1.98 & 0.68 \\
\hline No & 27 & 100.0 & 13 & 92.9 & & \\
\hline \multicolumn{7}{|l|}{ Contact with cats } \\
\hline Yes & 19 & 70.4 & 0 & 0.0 & 18.36 & $<0.0001$ \\
\hline No & 8 & 29.6 & 14 & 100.0 & & \\
\hline \multicolumn{7}{|l|}{ Contact with soil } \\
\hline Yes & 23 & 85.2 & 0 & 0.0 & 27.17 & $<0.0001$ \\
\hline No & 4 & 14.8 & 14 & 100.0 & & \\
\hline
\end{tabular}

${ }^{*} p<0.0001$ high significant difference

$p>0.05$ non-significant difference
Table 4 Relation between anti-Toxoplasma IgG prevalence and clinical findings among patients (group 1)

\begin{tabular}{|c|c|c|c|c|c|c|}
\hline & \multicolumn{6}{|c|}{ Anti-Toxoplasma lgG (seropositivity) } \\
\hline & \multicolumn{2}{|c|}{ Positive } & \multicolumn{2}{|c|}{ Negative } & \multirow[t]{2}{*}{$x^{2}$} & \multirow{2}{*}{$\begin{array}{l}p \\
\text { value }\end{array}$} \\
\hline & No. & $\%$ & No. & $\%$ & & \\
\hline \multicolumn{7}{|c|}{ Retinopathy } \\
\hline Yes & 12 & 44.4 & 14 & 42.4 & $0.02^{*}$ & 0.88 \\
\hline No & 15 & 55.6 & 19 & 57.6 & & \\
\hline \multicolumn{7}{|c|}{ Nephropathy } \\
\hline Yes & 2 & 7.4 & 1 & 3.0 & 0.599 & 0.58 \\
\hline No & 25 & 92.6 & 32 & 97.0 & & \\
\hline \multicolumn{7}{|c|}{ Neuropathy } \\
\hline Yes & 4 & 14.8 & 4 & 12.1 & 0.09 & 1.0 \\
\hline No & 23 & 85.2 & 29 & 87.9 & & \\
\hline \multicolumn{7}{|c|}{ Liver disease } \\
\hline Yes & 1 & 3.7 & 1 & 3.0 & $0.021^{*}$ & 1.0 \\
\hline No & 26 & 96.3 & 32 & 97.0 & & \\
\hline \multicolumn{7}{|l|}{ Cancer } \\
\hline Yes & 1 & 3.7 & 2 & 6.1 & 0.174 & 1.0 \\
\hline No & 26 & 96.3 & 31 & 93.9 & & \\
\hline
\end{tabular}

${ }^{*} p<0.05$ statistically significant difference

$p>0.05$ non-significant

seropositive. No statistically significant differences could be detected between the clinical findings among patients with type I DM group and Toxoplasma seropositivity.

\section{Discussion}

The aim of this study was to determine the seroprevalence of Toxoplasma gondii among a group of patients with type I diabetes mellitus and to detect the relationship between Toxoplasma gondii infection and auto-reactive antibodies.

Overall, the current hypothesis suggests that toxoplasmosis increases susceptibility to acquiring diabetes and, on the other hand, diabetic patients are more vulnerable to opportunistic infections such as toxoplasmosis (Zhu et al. 2006; Gokce et al. 2008; Shirbazou et al. 2013; Saki et al. 2016).

In our study, the overall seroprevalence of toxoplasmosis in diabetic patients was $45.0 \%$ which was in agreement with $46 \%$ reported as by Hemida et al. (2017) while it was lower than $57.2 \%$ as reported by Gokce et al. (2008), higher than $16.5 \%$ as reported by $\mathrm{Li}$ et al. (2018) in China, and much higher than $5.4 \%$ as reported by Krause et al. (2009). It has been found that seroprevalence of $T$. gondii infection was significantly higher in cases than in controls $(\mathrm{OR}=2.69 ; 95 \% \mathrm{CI} 1.23-5.89 ; p=0.01)$ which was incompatible with the results reported by Gokce et al. (2008) $(\mathrm{OR}=5.066$; 95\% CI 2.579-9.952; $p=<0.001)$, Hemida et al. (2017) $(p=0.03)$, and $\mathrm{Li}$ et al. (2018). However, Siyadatpanah et al. (2013) found no statistically 
significant difference in the prevalence of toxoplasmosis between diabetics and non-diabetic individuals.

Concerning the association between age and seropositivity in the study population, there was a non-significant higher prevalence of seropositivity(IgG) among age group above 30 years old ( $81.5 \%$ and $85.7 \%)$ for the cases and control group respectively. The reason might be the increased possibility of an individual coming into contact with one of the transmission routes (Ajioka and Soldati 2007; Spalding et al. 2005). Similarly, Shin et al. (2009) reported that the prevalence of toxoplasmosis tended to be increased with age, and also, this increase was not statistically significant. On the other hand, Hemida et al. (2017) found a non-significant negative relation between seropositivity and increase in age.

With respect to gender, the seropositivity for antiToxoplasma IgG among females was higher than that among males, but the difference was not significant. Similar results were obtained in the survey performed at Al-Hussien University Hospital, Cairo, Egypt (Hemida et al. 2017), on Cheju Island, Korea (Yang et al. 2000), and Seoul National University Children's Hospital, Korea (Kook et al. 1999). In contrast, a report has been made that male patients had a higher infection rate than female patients at Kangnam St. Mary's Hospital, Korea (Choi et al. 1989).

All patients were subjected to fulfill a questionnaire sheet to verify the possible risk factors of Toxoplasma infection and to evaluate the environmental and socioeconomic pattern of both cases and control groups. In our study, there was no statistical difference in seroprevalence between rural and urban areas ( $p$ value $=0.86$ ) that agreed with what has been found with Hemida et al. (2017), although it was demonstrated in other studies that living in rural areas had a higher risk of toxoplasmosis than those in urban areas (Garcia et al. 1999).

According to the present data, there was a statistically significant difference regarding the consumption of undercooked meat, contact with cats and contact with soil, and Toxoplasma seroprevalence. The participants who frequently do gardening were highly infected (85.2\%) compared with the ones who did not spend time in contact with soil (14.8\%). This could be explained due to the fact that the buried sporulated oocysts of cats might be contaminating the soil and sand and the oocysts remain infectious for several months and can last beyond 1 year (Frenkel and Dubey 1972).

Kapperud et al. (1996), Bobić et al. (1998), and Cook et al. (2000) demonstrated a significant association between eating raw or unwashed vegetables and fruits and Toxoplasma gondii seroconversion. Spalding et al. (2005) and Jones et al. (2005) reported that this mode of infection is possibly responsible for Toxoplasma infection in vegetarians and herbivores. Kapperud et al.
(1996), Baril et al. (1999), and Kravetz and Federman (2005) emphasized the relevance of cats in toxoplasmosis as the most likely method for transmission. Epidemiological studies and several outbreaks have identified the handling and consumption of raw or undercooked meat as a source of toxoplasmosis (Cook et al. 2000; Ross et al. 2001; Carme et al. 2002 and Dubey and Jones 2008).

The present study revealed that no patients gave history of fever with lymphadenopathy, while 26 patients (43.3\%) had a history of retinopathy. Previous studies reported that Toxoplasma infection is often clinically silent (Thulliez 1992; Gorgievski-Hrisoho et al. 1996; Remington et al. 2001 and Nimri et al. 2004; Kravetz and Federman 2005). However, Montoya (2002) demonstrated that fever, lymphadenopathy, and retinochoroiditis were suggestive presentations of toxoplasmosis.

To clarify the characteristics of $T$. gondii-seropositive diabetic patients, the patients' medical records were checked. The major coincidental diseases in seropositive patients were retinopathy, nephropathy, neuropathy, liver disease, and cancer. Shin et al. (2009) reported that major co-morbidities of seropositive patients included malignant neoplasms, diabetes mellitus, arthritis, chronic hepatitis B, chronic renal diseases, schizophrenia, and acute lymphadenitis.

In the present study, no association could be detected between Toxoplasma gondii infection and auto-reactive antibodies.

\section{Conclusion}

In the present study, the overall seroprevalence of toxoplasmosis in diabetic patients was $45.0 \%$. A significant association was detected between consumption of undercooked meat, contact with cats and contact with soil, and Toxoplasma seroprevalence (possible risk factors of Toxoplasma infection). The major coincidental diseases in seropositive patients were retinopathy, nephropathy, neuropathy, liver disease, and cancer. No association could be detected between Toxoplasma gondii infection and auto-reactive antibodies. The absence of specific antibodies does not exclude active disease in immune-suppressed patients whom toxoplasmosis is suspected. So, additional diagnostics methods including PCR amplification of $T$. gondii are strongly recommended. A prospective exposure-outcome study is suggested to investigate the effect of Toxoplasma infection in individuals with auto-reactive anti-islet antibodies in children and adolescents with a family history of diabetes mellitus type 1 on disease outcome.

\section{Acknowledgements}

We would like to thank all team members of Diabetic clinic at the Research Institute of Ophthalmology (RIO), as well as all attendants for their participation and kind assistance. 


\section{Funding}

The work was self-funded by the authors.

\section{Availability of data and materials}

Data on which the conclusions of this work were based on are all presented in the manuscript and its additional files.

\section{Authors' contributions}

All authors have contributed significantly to the conception and design of the study, acquisition and interpretation of data, the clinical work, and the drafting and revision of the manuscript. All authors read and approved the final manuscript.

\section{Ethics approval and consent to participate}

Informed consent was obtained from the parents and/or caregivers of all participants before the procedure, according to the guidelines of the ethical committee.

\section{Consent for publication}

We have approved the manuscript for submission to your journal hoping that it is going to be accepted for publication.

\section{Competing interests}

The authors declare that they have no competing interests.

\section{Publisher's Note}

Springer Nature remains neutral with regard to jurisdictional claims in published maps and institutional affiliations.

\section{Author details}

${ }^{1}$ Medical Parasitology Department, Research Institute of Ophthalmology, Giza, Egypt. ${ }^{2}$ Medical Parasitology Department, Faculty of Medicine, Cairo University, Cairo, Egypt. ${ }^{3}$ Public Health Department, Research Institute of Ophthalmology, Giza, Egypt.

Received: 20 November 2018 Accepted: 21 January 2019 Published online: 04 February 2019

\section{References}

Ajioka JW, Soldati D (2007) Toxoplasma-molecular and cellular biology. Horizon Bioscience, Norfolk, pp 37-58

Baril L, Ancelle T, Goulet V, Thulliez P, Tirard-Fleury V, Carme B (1999) Risk factors for Toxoplasma infection in pregnancy: a case-control study in France. Scand $J$ Infect Dis 31(3):305-309

Benoist C, Mathis D (2001) Autoimmunity provoked by infection: how good is the case for T cell epitope mimicry? Nat Immunol 2(9):797-801

Bobić B, Jevremović I, Marinković J, Šibalić D, Djurković-Djaković O (1998) Risk factors for Toxoplasma infection in a reproductive age female population in the area of Belgrade, Yugoslavia. Eur J Epidemiol 14(6):605-610

Carme B, Bissuel F, Ajzenberg D, Bouyne R, Aznar C, Demar M, Bichat S, Louvel D, Bourbigot AM, Peneau C, Neron P, Dardé ML (2002) Severe acquired toxoplasmosis in immunocompetent adult patients in French Guiana. J Clin Microbiol 40(11):4037-4044

Cavallazzi LO (1985) Toxoplasmosis of the central nervous system in a diabetic patient. Arq Neuropsiquiatr 43(3):319-321

Chadha V (2006) Sample size determination in health studies. NTI Bull 42:55-62

Choi WY, Nam HW, Youn JH, Kim WS, Kim WK (1989) Toxoplasma antibody titers by indirect latex agglutination test in patients of Kangnam St. Mary's Hospital and Cheju Medical Center. Korean J Parasitol 27:171-175

Cook AJC, Gilbert RE, Buffolano W, Zufferey J, Petersen E, Jenum PA, Foulon W, AEi S, Dunn DT (2000) Sources of toxoplasma infection in pregnant women: European multicentre case-control study. BMJ 321:142-147

Daniel WW (2005) Chapter 12: the Chi square distribution and the analysis or frequencies. In: Biostatistics: a foundation for analysis in the health sciences, 8th edn. John Wiley \& Sons Inc, Hoboken. ISBN-10: 0471746525 ISBN-13: 978 0471746522. pp 593-674

Dubey JP (2005) Toxoplasmosis. In: Cox FFG, Wakelin D, Gillespie SH, Despommier D (eds) Topley and Wilson's microbiology and microbia infections: parasitology, vol 5, 10th edn. Arnold, London
Dubey JP, Jones JL (2008) Toxoplasma gondii infection in humans and animals in the United States. Send to Int J Parasitol 38(11):1257-1278. https://doi.org/10. 1016/j.jpara.2008.03.007

Frenkel J, Dubey J (1972) Toxoplasmosis and its prevention in cats and man. J Infect Dis 126:664-673. https://doi.org/10.1093/infdis/126.6.664

Garcia JL, Navarro IT, Ogawa L, de Oliveira RC, Kobilka E (1999) Seropervalence, epidemiology and ocular evaluation of human toxoplasmosis in the rural zone jauguapita (Parana) Brazil. Rev Panam Salud Publica 6(3):157-163

Gokce C, Yazar S, Bayram F, Gundogan K (2008) Toxoplasma gondii antibodies in type 1 diabetes mellitus. Turk Klin Tip Bilim 28:619-622

Gorgievski-Hrisoho M, Germann D, Matter L (1996) Diagnostic implications of kinetics of immunoglobulin $\mathrm{M}$ and antibody responses to Toxoplasma gondii. J Clin Microbiol 34(6):1506-1511

Hemida MH, Shahat SA, AMS B, Mohammad KA (2017) Prevalence of toxoplasmosis among diabetic patients. Ejpmr 4(11):137-140

Jones JL, Lopez A, Wilson M, Schulkin J, Gibbs R (2001) Congenital toxoplasmosis: a review. Obstet Gynecol Surv 56(5):296-305

Jones JL, Lopez B, Alvarez Mury M, Wilson M, Klein R, Luby S, Maguire JH (2005) Toxoplasma gondii infection in rural Guatemalan children. Am J Trop Med Hyg 72(3):295-300

Joshi N Caputo GM, Weitekamp MR, Karchmer AW (1999) Infections in patients with diabetes mellitus. N Engl J Med 341(25):1906-1912

Kapperud G, Jenum PA, Stray-Pedersen B, Melby KK, Eskild A, Eng J (1996) Risk factors for Toxoplasma gondii infection in pregnancy. Results of a prospective case-control study in Norway. Am J Epidemiol 144(4):405-412

Kook J, Lee HJ, Kim BI, Yun CK, Guk SM, Seo M, Park YK, Hong ST, Chai JY (1999) Toxoplasma gondii antibody titers in sera of children admitted to the Seoul National University Children' Hospital. Korean J Parasitol 37:27-32

Krause I, Anaya JM, Fraser A, Barzilai O, Ram M, Abad V, Arango A, Garc'ia J, Shoenfeld Y (2009) Anti-infectious antibodies and autoimmune-associated autoantibodies in patients with type I diabetes mellitus and their close family members. Ann N Y Acad Sci 1173:633-639

Kravetz JD, Federman DG (2005) Toxoplasmosis in pregnancy. Am J Med 118(3): $212-216$

Li YX, Xin H, Zhang X, Wei C, Duan Y, Wang H, Niu H (2018) Toxoplasma gondii infection in diabetes mellitus patients in China: Seroprevalence, risk factors, and case-control studies. BioMed Res Int 2018:1-9 Article ID 4723739 https:// doi.org/10.1155/2018/4723739

Montoya JG (2002) Laboratory diagnosis of Toxoplasma gondii infection and toxoplasmosis. J Infect Dis 185(Suppl 1):S73-S582

Montoya JG, Giraldo LF, Efron B, Stinson EB, Gamberg P, Hunt S, Giannetti N, Miller J, Remington JS (2001) Infectious complications among 620 consecutive heart transplant patients at Stanford University Medical Center. Clin Infect Dis 33(5):629-640

Nimri L, Pelloux H, Elkhatib L (2004) Detection of Toxoplasma gondii DNA and specific antibodies in high-risk pregnant women. Am J Trop Med Hyg 71(6):831-835

Olefsky JM (1985) Diabetes mellitus. In: Wyngaarden JB, Smith LH (eds) Cecil textbook of medicine, 17th edn. WB Saunders, Philadelphia, pp 1320-1339

Orci L, Vassalli JD, Perrelet A (1988) The insulin factory. Sci Am 259(3):85-94

Remington, JS. McLeod P, Thulliez P and Desmonts J G (2001): Toxoplasmosis, p. 205-346. In J. S. Remington and J. Klein (ed.), Infectious diseases of the fetus and newborn infant, 5th ed. W. B. Saunders, Philadelphia

Remington JS, Thulliez P, Montoya JG (2004) Recent developments for diagnosis of toxoplasmosis. J Clin Microbiol 42(3):941-945

Ross RD, Stec LA, Werner JC, Blumenkranz MS, Glazer L, Williams GA (2001) Presumed acquired ocular toxoplasmosis in deer hunters. Retina 21:226-229

Saki J, Shafieenia S, Foroutan-Rad M (2016) Seroprevalence of toxoplasmosis in diabetic pregnant women in southwestern of Iran. J Parasit Dis:1-4 https:// doi.org/10.1007/s12639-015-0735-4

Sensini A (2006) Toxoplasma gondii infection in pregnancy: opportunities and pitfalls of serological diagnosis. Clin Microbiol Infect 12(6):504-512

Shin DW, Cha DY, Hua QJ, Cha GH, Lee YH (2009) Seroprevalence of Toxoplasma gondii infection and characteristics of seropositive patients in general hospitals in Daejeon, Korea. Korean J Parasitol 47(2):125-130

Shirbazou S, Delpisheh A, Mokhetari R, Tavakoli G (2013) Serologic detection of anti Toxoplasma gondii infection in diabetic patients. Iran Red Crescent Med J 15(8):701-703 doi: 10.5812

Siyadatpanah A, Tabatabaie F, Oormazdi H et al (2013) Comparison of antiToxoplasma IgG and IgM antibodies determined by ELISA method in diabetic and non-diabetic individuals in west Mazandaran province, Iran, 2011-2012. Ann Biol Res 4:281-285 
Spalding SM, Amendoeira MR, Klein CH, Ribeiro LC (2005) Serological screening and toxoplasmosis exposure factors among pregnant women in south of Brazil. Rev Soc Bras Med Trop 38:173-177

Tenter AM, Heckeroth AR, Weiss LM (2000) Toxoplasma gondii: from animals to humans. Int J Parasitol 30(12-13):1217-1258

Thulliez P (1992) Screening programme for congenital toxoplasmosis in France. Scand I Infect Dis Suppl 84:43-45

WHO (2011) Use of glycated haemoglobin (HbA1c) in the diagnosis of diabetes mellitus. World Health Organization, Geneva

Yamamoto JH, Boletti DI, Nakashima Y, Hirata CE, Olivalves E, Shinzato MM, Okay TS, Santo RM, Duarte MI, Kalil J (2003) Severe bilateral necrotising retinitis caused by Toxoplasma gondii in a patient with systemic lupus erythematosus and diabetes mellitus. Br J Ophthalmol 87(5):651-652

Yang HJ, Jin KN, Park YK, Hong SC, Bae JM, Lee SH, Choi HS, Hwang HS, Chung YB, Lee NS, Nam HW (2000) Seroprevalence of toxoplasmosis in the residents of Cheju island, Korea. Korean J Parasitol 38:91-93

Youinou P, Pers JO, Gershwin ME, Shoenfeld Y (2010) Geo-epidemiology and autoimmunity. J Autoimmun 34(3):J163-J167

Zhu S, Lai DH, Li SQ, Lun ZR (2006) Stimulative effects of insulin on Toxoplasma gondii replication in 3T3-L1 cells. Cell Biol Int 30:149-153

\section{Submit your manuscript to a SpringerOpen ${ }^{\circ}$ journal and benefit from:}

- Convenient online submission

- Rigorous peer review

- Open access: articles freely available online

High visibility within the field

- Retaining the copyright to your article

Submit your next manuscript at $\boldsymbol{\nabla}$ springeropen.com 